\author{
Asian Economic and Financial Review \\ $\operatorname{ISSN}(e): \quad 2222-6737$ \\ $\operatorname{ISSN}(p): \quad 2305-2147$ \\ DOI: $10.18488 /$ journal.aefr.2020.108.946.955 \\ Vol. 10, No. 8, 946-955. \\ (C) 2020 AESS Publications. All Rights Reserved. \\ URL: www.aessweb.com \\ check for
}

\title{
FDI INFLOWS AND FINANCIAL DEVELOPMENT IN ECOWAS: CAUSALITY ANALYSIS IN THE FREQUENCY DOMAIN
}

Koffi Pokou

\author{
Dept of Economics, University FHB, Abidjan, Cote d'Ivoire. \\ Email:engene.kouassi@gmail.com
}

(1) Check for updates

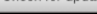

Tokou

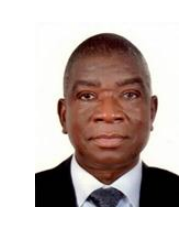

Article History
Received: 29 May 2020
Revised: 8 July 2020
Accepted: 12 August 2020
Published: 24 August 2020
Keywords
Financial development
Foreign direct investment
Inflows
Frequency-domain
Granger
Causality
ECOWAS.

JEL Classification: C32; G10; O16.

\begin{abstract}
Many studies have attempted to highlight the causal relationship between the inflows of Foreign Direct Investments (FDI) and the financial development with mitigated success in African countries, especially in ECOWAS member countries. For the most part, these studies have simply showed the importance of FDI and financial development in achieving GDP. To refocus the debate, this article analyzes in ECOWAS member countries the causal relationship between our variables of interest using recent causality techniques: time domain Granger (1969), Toda and Yamamoto (1995) and Breitung and Candelon (2006). Overall, country-by-country estimates revealed evidence of significant links between FDI inflows and financial sector development in terms of unidirectional as well as bidirectional causalities. Essentially, the findings imply that policymakers should not only address the causal direction between FDI inflows and financial development but also whether it is temporal or permanent and therefore authorities must define measures to be taken accordingly.
\end{abstract}

Contribution/ Originality: It is the first time the relationship between the inflows of FDI and the financial development in ECOWAS member countries has been analyzed by using the techniques mentioned above. These methods provide robust estimations. The findings suggest that the causality between financial development and FDI are mixed across different frequencies leading to varied policy designs.

\section{INTRODUCTION}

Over the last two decades, foreign investments has become an essential source of external capital complementary to domestic capital for Africa and especially in West African countries, which require substantial capital to sustain their development (Agosin \& Machado, 2005; Seetanah, 2009).Several advantages of foreign direct investment (FDI) have been detected in the literature: for instance, fostering the technology diffusion process, acquisition of more developed management practices, poverty alleviation and productivity gain.

The literature indicates that the benefits mentioned above are contingent on the absorptive capacity of the host country. Among the important absorptive capacities considered in the literature, there are the quality of human capital (Borensztein et al., 1998) and the financial sector development (Adjasi et al., 2012; Durham, 2004; Hermes \& Lensink, 2003). However, the direct relationship between FDI and financial development has received little attention. The idea that financial development matters in the relation between FDI and economic growth has been studied extensively (Alfaro et al., 2004, 2010; Bekaert et al., 2005; Hermes \& Lensink, 2003; Levine et al., 2000; 
Levine \& Zervos, 1998)) with insufficient insight of the direct causal association between FDI flows and financial development, particularly in West African countries where the financial sector is in the development phase. Empirical studies in this field are interested in the role of the financial sector as a channel of FDI in the process of economic production (Alfaro et al., 2004; Hermes \& Lensink, 2003).

Notwithstanding this deficit of contributions studying the direct causal relation between FDI flows and financial development, the literature offers some empirical papers that have explored FDI-financial sector development nexus (Al Nasser \& Gomez, 2009; Bayar \& Ozel, 2014; Desbordes \& Wei, 2017; Enisan, 2017; Fauzel, 2016; Korgaonkar, 2012; Sahina \& Egeb, 2015; Zakaria, 2007). Korgaonkar (2012) applied a data mining technique on 78 countries during the 1980 to 2009 period and found that financial development remained a prerequisite for attracting FDI inflows.

Agbloyor et al. (2013) studied links concerning financial markets and FDI in Africa using 2SLS method through a panel data and established significant bidirectional causality in FDI-financial markets relation. Desbordes \&Wei (2017) examined the link amid FDI flows and financial development in source and destination countries during the period 2003-2006. The findings of the panel data regression pointed out those countries desiring to encourage firm's internationalization and attract foreign multinationals ought to promote actions to increase access on external financing. Focusing on a panel data of emerging markets. As for Soumaré \&Tchana (2015), they explored the causality among FDI and financial market development and they argued that there is a two-way causal link between FDI and stock market proxies, but the link is unclear and inconclusive as regard the banking sector proxies. Gebrehiwot et al. (2016) studied causality on financial development-FDI nexus for eight African nations during 1991-2013 period and documented a bidirectional causality between variables. The contribution of Otchere et al. (2016) who has studied the direct causal linkage between FDI and financial markets in Africa, has demonstrated two-way causality and suggested a positive relationship between the variables. Yilmaz \& Gavriletea (2018) assessed the connection between FDI inflows and financial development in CEEU countries from 1996 to 2015 by means of panel cointegration and causality approaches. They found no cointegration relation between FDI inflows, investments of foreign portfolio, and financial sectors, however they showed that unidirectional causality from financial development to FDI inflows exist as concern the short term. More recently, Njangang et al.(2019) analysed the long and short-term impacts of FDI inflows on financial development in forty-nine African economies from 1990 to 2016 and found that FDI stimulate financial sector development over the long term. This article contributes to the literature of FDI inflows and financial development by using the frequency domain causality test to assess short-, medium and long-term causality and seeks to show whether the direction of causality vary along the periods.

Among the studies consecrated exclusively on the relation between FDI inflows and financial development, this is the first evidence, which explores causal relation between these two notions in the frequency domain analysis in the case of West African countries. Investment is essential to fostering the West Africa economy. Despite the relatively robust economic growth in West Africa in recent years, the region accounts for only around $1 \%$ of global FDI. Our examination of the causality among FDI inflows and financial development concerns a sample of fourteen ECOWAS economies. The rest of the study is organised as follows: Section 2 focuses on data description, Section 3 presents econometric methodology with empirical results in Section 4, and Section 5 concludes with final remarks.

\section{DATA DESCRIPTION}

The study used yearly data for fourteen countries of ECOWAS. According to the empirical literature on this topic, two different indicators were adopted to measure financial development, namely, liquid liabilities (LIAB) represent measure of "financial depth" (King \& Levine, 1993a; Shen \& Lee, 2006)) and domestic credit issued from

the banking sector to the private sector $(B A N K)$ indicate a measure of the size of the financial sector (King \& Levine, 1993a, 1993b). FDI inflows had as a measure the net inflows of FDI. The period of the study was delimited 
by the obtainability of data for each country. Our different variables were expressed in-percentage of GDP. Data were extracted from the Global Financial Development and World Development Indicators in the World Bank database. Table 1 proposes summary statistics of the series used and the countries in our sample.

Table-1. Descriptive statistic

\begin{tabular}{|c|c|c|c|c|c|c|}
\hline Country & Variable & Mean & SD & Min & $\operatorname{Max}$ & $\mathbf{T}$ \\
\hline \multirow[t]{3}{*}{ Benin } & FDI & 1.232 & 1.683 & -0.9 & 6.08 & 38 \\
\hline & LIAB & 26.157 & 6.87 & 13.379 & 42.856 & 37 \\
\hline & BANK & 18.062 & 8.087 & 5.415 & 31.84 & 38 \\
\hline \multirow[t]{3}{*}{ Burkina-Faso } & FDI & 0.726 & 1.045 & -0.092 & 4.104 & 38 \\
\hline & LIAB & 21.072 & 5.519 & 12.304 & 35.145 & 37 \\
\hline & BANK & 15.059 & 5.976 & 6.649 & 31.257 & 38 \\
\hline \multirow[t]{3}{*}{ Cabo Verde } & FDI & 4.884 & 3.86 & -0.005 & 12.667 & 32 \\
\hline & LIAB & 56.14 & 21.287 & 27.344 & 98.847 & 37 \\
\hline & BANK & 29.65 & 23.385 & 1.664 & 65.278 & 38 \\
\hline \multirow[t]{3}{*}{ Cote d'Ivoire } & FDI & 1.319 & 1.004 & -2.07 & 3.543 & 38 \\
\hline & LIAB & 27.691 & 4.404 & 21.209 & 36.625 & 37 \\
\hline & BANK & 24.316 & 9.987 & 12.372 & 41.871 & 38 \\
\hline \multirow[t]{3}{*}{ Gambia, The } & FDI & 3.009 & 3.368 & -1.072 & 12.55 & 38 \\
\hline & LIAB & 26.084 & 13.461 & 13.654 & 53.66 & 35 \\
\hline & BANK & 11.449 & 6.428 & 3.507 & 24.885 & 38 \\
\hline \multirow[t]{3}{*}{ Ghana } & FDI & 2.916 & 2.98 & 0.045 & 9.517 & 38 \\
\hline & LIAB & 15.746 & 7.944 & 6.339 & 32.064 & 37 \\
\hline & BANK & 8.948 & 5.092 & 1.542 & 15.827 & 38 \\
\hline \multirow[t]{3}{*}{ Guinea } & FDI & 2.45 & 4.268 & -0.84 & 18.809 & 32 \\
\hline & LIAB & 13.004 & 6.935 & 5.647 & 25.257 & 26 \\
\hline & BANK & 4.909 & 2.268 & 2.627 & 10.775 & 29 \\
\hline \multirow[t]{3}{*}{ Guinea-Bissau } & FDI & 1.303 & 1.071 & 0.016 & 4.274 & 34 \\
\hline & LIAB & 17.403 & 13.732 & 0.11 & 47.007 & 31 \\
\hline & BANK & 6.894 & 4.524 & 0.403 & 18.501 & 28 \\
\hline \multirow[t]{3}{*}{ Mali } & FDI & 1.586 & 1.757 & -0.773 & 6.351 & 38 \\
\hline & LIAB & 20.155 & 4.317 & 14.135 & 27.236 & 37 \\
\hline & BANK & 15.954 & 4.717 & 7.341 & 27 & 38 \\
\hline \multirow[t]{3}{*}{ Niger } & FDI & 2.933 & 4.549 & -2.138 & 16.629 & 38 \\
\hline & LIAB & 16.147 & 4.793 & 7.294 & 26.549 & 37 \\
\hline & BANK & 11.074 & 4.825 & 3.3 & 17.39 & 38 \\
\hline \multirow[t]{3}{*}{ Nigeria } & FDI & 1.717 & 1.325 & -1.151 & 5.791 & 38 \\
\hline & LIAB & 18.241 & 7.307 & 9.609 & 33.864 & 37 \\
\hline & BANK & 9.608 & 4.312 & 4.948 & 22.267 & 38 \\
\hline \multirow[t]{3}{*}{ Senegal } & FDI & 1.167 & 1.005 & -0.988 & 2.976 & 38 \\
\hline & LIAB & 28.052 & 7.907 & 19.958 & 46.133 & 37 \\
\hline & BANK & 20.035 & 5.968 & 11.536 & 29.537 & 38 \\
\hline \multirow[t]{3}{*}{ Sierra Leone } & FDI & 3.097 & 8.637 & -28.624 & 32.301 & 38 \\
\hline & LIAB & 12.575 & 4.743 & 6.024 & 23.322 & 37 \\
\hline & BANK & 4.277 & 1.872 & 1.522 & 8.159 & 38 \\
\hline \multirow[t]{3}{*}{ Togo } & FDI & 2.366 & 3.228 & -1.384 & 18.818 & 38 \\
\hline & LIAB & 34.993 & 9.097 & 20.918 & 52.472 & 37 \\
\hline & BANK & 23.089 & 7.852 & 11.473 & 41.708 & 38 \\
\hline
\end{tabular}




\section{ECONOMETRIC METHODOLOGY}

As stated above, the main purpose of the current research was to assess the Granger causal relation among FDI inflows and financial development indicators in ECOWAS over different frequencies, therefore, we performed the Breitung and Candelon (2006) test originally introduced by Geweke (1982) and got the results below:

Setting $z_{t}=\left[x_{t}, y_{t}\right]^{\prime}$ a two-dimensional vector over the time $t=1, \ldots, T$. Vector $z_{t}$ has a finite-order VAR formulation such as:

$$
\Theta(L) z_{t}=\varepsilon_{t}
$$

where $\Theta(L)=I-\Theta_{1} L-\ldots-\Theta_{p} L^{p} ; \Theta(L)$ is a $2 \times 2$ lag polynomial with $L^{k} z_{t}=z_{t-k}$. The error vector $\varepsilon_{t}$ is white noise with $E\left(\varepsilon_{t}\right)=0$ and $E\left(\varepsilon_{t} \varepsilon_{t}^{\prime}\right)=\Sigma$ where $\Sigma$ is positive definite. For ease of exposition, we neglect any deterministic terms in Equation 1.

Let $G G^{\prime}=\Sigma^{-1}$ such that $E\left(\eta_{t} \eta_{t}^{\prime}\right)=I$ and $\eta_{t}=G \varepsilon_{t}, G$ corresponds to the Cholesky decomposition of the lower triangular matrix. The Moving Average (MA) formulation of the system under the stationarity assumption is:

$$
\begin{aligned}
z_{t} & =\Phi(L) \varepsilon_{t}=\left[\begin{array}{ll}
\Phi_{11}(L) & \Phi_{12}(L) \\
\Phi_{21}(L) & \Phi_{22}(L)
\end{array}\right]\left[\begin{array}{l}
\varepsilon_{1 t} \\
\varepsilon_{2 t}
\end{array}\right] \\
& =\Psi(L) \eta_{t}=\left[\begin{array}{ll}
\Psi_{11}(L) & \Psi_{12}(L) \\
\Psi_{21}(L) & \Psi_{22}(L)
\end{array}\right]\left[\begin{array}{l}
\eta_{1 t} \\
\eta_{2 t}
\end{array}\right]
\end{aligned}
$$

where $\Phi(L)=\Theta(L)^{-1}$ and $\Psi(L)=\Phi(L) G^{-1}$.

The spectral density of $x_{t}$ is formulated as:

$$
f_{x}(\omega)=\frac{1}{2 \pi}\left\{\left|\Psi_{11}\left(e^{-i \omega}\right)\right|^{2}+\left|\Psi_{12}\left(e^{-i \omega}\right)\right|^{2}\right\}
$$

In light of Geweke (1982) the measure of causality is expressed as:

$$
\begin{array}{r}
M_{y \rightarrow x}(\omega)=\log \left[\frac{2 \pi f_{x}(\omega)}{\left|\Psi_{11}\left(e^{-i \omega}\right)\right|^{2}}\right] \\
=\log \left|1+\frac{\left|\Psi_{12}\left(e^{-i \omega}\right)\right|^{2}}{\left|\Psi_{11}\left(e^{-i \omega}\right)\right|^{2}}\right|
\end{array}
$$

Equation 6 is zero if $\left|\Psi_{12}\left(e^{-i \omega}\right)\right|^{2}=0$ indicates that $y$ does not cause Granger cause $x$ at frequency $\omega$.

Based on above equations, Breitung and Candelon (2006) reformulated the relationship between $x$ and $y$ in the VAR equation: 


$$
x_{t}=a_{1} x_{t-1}+\ldots+a_{p} x_{t-p}+\beta_{1} y_{t}+\ldots+\beta_{p} y_{t-p}+\varepsilon_{1 t}
$$

The null hypothesis $M_{y \rightarrow x}(\omega)=0$ corresponds to the linear restriction such that

$$
H_{0}: R(\omega) \beta=0
$$

with $\beta=\left(\beta_{1}, \ldots, \beta_{p}\right)^{\prime}$ the vector of coefficients of $y$ and

$$
R(\omega)=\left[\begin{array}{c}
\cos (\omega) \cos (2 \omega) \ldots \cos (p \omega) \\
\sin (\omega) \sin (2 \omega) \ldots \sin (p \omega)
\end{array}\right]
$$

The Fisher statistic $(F)$ for $(8)$ is distributed as

$$
\left\{\begin{array}{l}
F(2, T-2 p) \text { for } \omega \in(0, \pi) \\
\text { with: } \\
2 \text { the numbers of restriction } \\
T \text { the number of observations in the } \operatorname{VAR}(p)
\end{array}\right.
$$

On the other hand, the optimal lag order in $\operatorname{VAR}(p)$ Equation 1 is preferred for $p \geq 3$, because for $p=1$ and $p=2$, the $F$-statistic is constant for all frequencies $x$. This approach does not require to test unit root or cointegration among series. As claimed in Breitung and Candelon (2006) frequency domain causality test is robust to unit roots and cointegration properties for the VAR model augmented by $k(=1)$ and the restrictions tested with a $\operatorname{VAR}(p+k)$. Lemmens, Croux, and Dekimpe (2008) indicate that Bayesian Information Criterion (BIC) executes suitably in frequency domain causality test. Therefore, this study applies BIC for defining the optimal lag length $p$ in the VAR model.

\section{EMPIRICAL RESULTS}

We determined empirically the causal direction between FDI and financial development via the frequency domain analysis at a high $(\omega=2,5)$, a medium $(\omega=1,5)$ and a low $(\omega=0,5)$ frequency. These frequencies denote the permanent -, the intermediate-, and the temporary causality, respectively. For comparison, we also performed the time domain causality test in the spirit of Toda and Yamamoto (1995) and Dolado and Lütkepohl (1996)1.

Table 2 presents the frequency domain causality test results between FDI and LIAB as a proxy of financial development for each country. Following these results, it appears that there is both permanent and temporary bidirectional causality between FDI and LIAB for Burkina-Faso, Guinea and Nigeria. Additionally, there is permanent causality for Benin, Gambia and Mali, and temporary causality for Benin, Ghana and Guinea-Bissau from FDI to LIAB. The findings also suggested unidirectional causality from FDI to LIAB in the intermediate term for Benin, Ghana, Guinea, Mali and Nigeria. For the relationship going from LIAB to FDI, there was evidence of unidirectional permanent causality for Cabo Verde and Sierra Leone, and unidirectional causality in the medium term for Burkina-Faso, Cabo Verde, Guinea and Nigeria. In most of the cases, there was no link between these

\footnotetext{
${ }^{1}$ See Ciner (2011) for more details about this discussion
} 
variables. The time domain causality test estimates between FDI and LIAB in columns 3 and 4 of Table 2 corroborate $^{2}$ the findings in the frequency domain.

Table-2. Results of frequency domain Granger-causality test between FDI and financial development (with LIAB as indicator).

\begin{tabular}{|c|c|c|c|c|c|c|c|c|c|}
\hline & \multirow[t]{3}{*}{$\begin{array}{l}\text { Data } \\
\text { range }\end{array}$} & \multicolumn{2}{|c|}{$\begin{array}{l}\text { Causality test results } \\
\text { in the time domain }\end{array}$} & \multicolumn{6}{|c|}{ Causality test results in the frequency domain } \\
\hline & & \multirow[t]{2}{*}{$\begin{array}{c}\text { FDI } \\
\text { 9LIAB }\end{array}$} & \multirow[t]{2}{*}{$\begin{array}{l}\text { LIAB } \\
\text { 9FDI }\end{array}$} & \multicolumn{3}{|c|}{ FDI 9LIAB } & \multicolumn{3}{|c|}{ LIAB 9FDI } \\
\hline & & & & $\begin{array}{l}\text { Permanent } \\
\omega=0,5\end{array}$ & $\begin{array}{c}\text { Mediu } \\
\text { m } \\
\omega=0,5\end{array}$ & $\begin{array}{l}\text { Temporary } \\
\omega=2,5\end{array}$ & $\begin{array}{l}\text { Permanent } \\
\qquad \omega=0,5\end{array}$ & $\begin{array}{l}\text { Medium } \\
\omega=0,5\end{array}$ & $\begin{array}{c}\text { Temporary } \\
\omega=2,5\end{array}$ \\
\hline Benin & $\begin{array}{l}1980- \\
2016\end{array}$ & $7.3856^{*}$ & 2.5796 & $4.6884^{*}$ & $5.5912^{*}$ & $5.8649^{*}$ & 0.6899 & 1.3923 & 1.5243 \\
\hline $\begin{array}{l}\text { Burkina } \\
\text {-Faso }\end{array}$ & $\begin{array}{l}1980- \\
2016\end{array}$ & $\begin{array}{c}12.419^{* * *} \\
*\end{array}$ & $\begin{array}{c}20.559^{* * *} \\
*\end{array}$ & $6.9925^{* *}$ & 1.2664 & $4.9841^{*}$ & $11.2558^{* * * *}$ & $\begin{array}{l}11.6536^{*} \\
\text { ** }\end{array}$ & $9.2982^{* * * *}$ \\
\hline $\begin{array}{l}\text { Cabo } \\
\text { Verde }\end{array}$ & $\begin{array}{l}1986- \\
2016\end{array}$ & 1.9237 & $11.176^{* * *}$ & 1.3060 & 1.1004 & 0.7229 & $8.0628^{* *}$ & 4.6032 & 3.8929 \\
\hline $\begin{array}{c}\text { Côte } \\
\text { d'Ivoire }\end{array}$ & $\begin{array}{l}1980- \\
2016\end{array}$ & 2.5069 & 1.7862 & 1.7276 & 1.3633 & 0.7856 & 0.6147 & 0.3501 & 0.5579 \\
\hline Gambia & $\begin{array}{l}1980- \\
2014\end{array}$ & 8.5966* & 1.4691 & $6.2107^{* *}$ & 0.3743 & 0.8194 & 0.8263 & 1.1346 & 1.1434 \\
\hline Ghana & $\begin{array}{l}1980- \\
2016\end{array}$ & 9.3692*** & $11.091^{* * *}$ & 0.2507 & $\begin{array}{c}7.4267^{*} \\
*\end{array}$ & $6.4017^{* *}$ & 2.6501 & 3.1184 & 3.7047 \\
\hline Guinea & $\begin{array}{l}1991- \\
2016\end{array}$ & $7.6005^{*}$ & $\begin{array}{c}34.742^{* * *} \\
*\end{array}$ & $5.2179^{*}$ & $5.0030^{*}$ & $4.7071^{*}$ & $16.2514^{* * * *}$ & $5.2195^{*}$ & $5.5670^{*}$ \\
\hline $\begin{array}{l}\text { Guinea } \\
\text { Bissau }\end{array}$ & $\begin{array}{l}1986- \\
2016\end{array}$ & 8.6635** & 2.2675 & 4.4680 & 0.8267 & $4.7127^{*}$ & 0.4268 & 0.9170 & 1.0684 \\
\hline Mali & $\begin{array}{l}1980- \\
2016\end{array}$ & $11.311^{*} *$ & 6.0278 & $8.9822^{* * *}$ & 3.1278 & 0.4699 & 3.8912 & 1.1789 & 1.5571 \\
\hline Niger & $\begin{array}{l}1980- \\
2016\end{array}$ & 5.3299 & 0.54347 & 4.2006 & 0.7904 & 0.3446 & 0.3901 & 0.2676 & 0.2736 \\
\hline Nigeria & $\begin{array}{l}1980- \\
2016 \\
\end{array}$ & $\begin{array}{c}12.224^{*} * * \\
*\end{array}$ & 11.545 & $8.2001^{* *}$ & $4.6523^{*}$ & $6.5373^{* *}$ & $5.7742^{*}$ & $6.5192^{* *}$ & $4.8119^{*}$ \\
\hline Senegal & $\begin{array}{l}1980- \\
2016\end{array}$ & 4.8191 & 5.1094 & 3.3344 & 2.7443 & 0.4671 & 4.0257 & 2.9338 & 2.7422 \\
\hline $\begin{array}{l}\text { Sierra } \\
\text { Leone }\end{array}$ & $\begin{array}{l}1980- \\
2016\end{array}$ & 5.9245 & $6.7129^{*}$ & 3.5431 & 3.0893 & 4.3133 & $5.3306^{*}$ & 3.4700 & 3.0797 \\
\hline Togo & $\begin{array}{l}1980- \\
2016\end{array}$ & 3.2275 & 1.5825 & 2.5068 & 1.2699 & 0.0521 & 1.0372 & 1.0827 & 0.9960 \\
\hline
\end{tabular}

Notes: This table presents the Granger causality tests between FDI and LIAB variables.

**** is for significance level of $1, * *$ for 5 and $*$ for $10 \%$.

Table 3 provides the causal nexus between $F D I$ and $B A N K$ for each country. The findings provided evidence of a bidirectional causality at all frequencies in the case of Cote d'Ivoire and permanent bidirectional causality for Guinea. There was permanent causality for Cabo Verde, Guinea Bissau and Mali, and temporary as well as intermediate causality for Guinea for the relationship running from $F D I$ to $B A N K$. Our findings also suggested a one-way causal nexus from FDI inflows to $B A N K$ at all frequencies for Togo. On the other hand, there was no evidence in most cases $^{3}$ of a causal link between FDI inflows and bank credit.

\footnotetext{
2 There is existence of causal link in Ghana for the frequencies around 0.25 .

${ }^{3}$ There is existence of causal link in Ghana for the frequencies around 0.25.
} 
Table-3. Results of frequency domain granger-causality test between FDI and financial development (with BANK as indicator).

\begin{tabular}{|c|c|c|c|c|c|c|c|c|c|}
\hline & \multirow[t]{3}{*}{ Data range } & \multicolumn{2}{|c|}{$\begin{array}{c}\text { Causality test results in the } \\
\text { time domain }\end{array}$} & \multicolumn{6}{|c|}{ Causality test results in the frequency domain } \\
\hline & & \multirow[t]{2}{*}{ FDI 9 BANK } & \multirow[t]{2}{*}{ BANK 9 FDI } & \multicolumn{3}{|c|}{ FDI 9BANK } & \multicolumn{3}{|c|}{ BANK 9FDI } \\
\hline & & & & $\begin{array}{c}\text { Permanent } \\
\omega=0,5\end{array}$ & $\begin{array}{c}\text { Medium } \\
\omega=0,5\end{array}$ & $\begin{array}{c}\text { Temporary } \\
\omega=2,5\end{array}$ & $\begin{array}{c}\text { Permanent } \\
\omega=0,5\end{array}$ & $\begin{array}{c}\text { Medium } \\
\omega=0,5\end{array}$ & $\begin{array}{c}\text { Temporar } \\
\text { y } \omega=2,5\end{array}$ \\
\hline Benin & $1980-2017$ & 3.2171 & 3.5233 & 1.5520 & 0.1991 & 1.1687 & 1.1862 & 1.0597 & 1.3317 \\
\hline Burkina-Faso & $1980-2017$ & 5.5387 & 0.33256 & 4.5181 & 0.3687 & 0.1514 & 0.2580 & 0.0532 & 0.0213 \\
\hline Cabo Verde & $1986-2017$ & $8.8285^{*}$ & 1.625 & $5.8526^{*}$ & 2.7997 & 4.2439 & 0.7774 & 0.2716 & 0.3110 \\
\hline Côte d'Ivoire & $1980-2017$ & $20.185^{* * * *}$ & $40.272 * * *$ & $16.3828 * * * *$ & $9.4538 * * *$ & $9.8112^{* * *}$ & $23.6606^{* * * *}$ & 7.3487 ** & $7.0944^{* * *}$ \\
\hline Gambia & $1980-2017$ & 1.6003 & 2.0264 & 0.9116 & 0.0465 & 0.3102 & 1.4704 & 0.1384 & 0.1117 \\
\hline Ghana & $1980-2017$ & 2.4507 & 7.8804 & 0.2173 & 1.9938 & 1.8245 & 4.2361 & 1.8279 & 2.6324 \\
\hline Guinea & 1989-2017 & $27.192^{* * * *}$ & $6.6846^{*}$ & $17.2103 * * * *$ & $17.2285^{* * * *}$ & $12.6009^{* * *}$ & $4.8834^{*}$ & 3.4161 & 3.4818 \\
\hline Guinea Bissau & $1990-2017$ & $10.366^{* *}$ & 1.4778 & $6.7872^{* *}$ & 0.5178 & 3.2229 & 1.0449 & 0.9149 & 0.8597 \\
\hline Mali & $1980-2017$ & $15.805^{* * * *}$ & 3.1363 & $12.0385 * * * *$ & 2.0223 & 0.9463 & 0.6126 & 2.4828 & 2.2268 \\
\hline Niger & 1980-2017 & 4.4114 & 3.032 & 3.5668 & 0.5906 & 0.2195 & 2.4733 & 1.3662 & 1.2277 \\
\hline Nigeria & $1980-2017$ & 2.162 & 4.4268 & 0.2506 & 1.6894 & 1.5739 & 2.4016 & 1.5416 & 1.9805 \\
\hline Senegal & $1980-2017$ & 3.4375 & 1.6787 & 2.7370 & 0.5002 & 0.1816 & 1.3686 & 0.7764 & 0.7042 \\
\hline Sierra Leone & 1980-2017 & 4.0556 & 1.9454 & 3.2921 & 1.0208 & 0.5875 & 1.4823 & 1.5012 & 1.5410 \\
\hline Togo & $1980-2017$ & $33.823^{*} * *$ & 1.6052 & 26.4481 **** & $15.3442^{*} * * *$ & $7.8590^{* *}$ & 0.2975 & 0.4354 & 0.7688 \\
\hline
\end{tabular}

Notes: This table presents the Granger causality tests between FDI and BANK variables.

**** is for significance level of $1, * *$ for 5 and $*$ for $10 \%$ 
According to the results provided in Table 2 and Table 3, it appears that the causal link between financial development and FDI is sensitive to different proxies employed as indicator of financial development and then findings concerning causality can differ if one modify the proxy of the financial development.

To summarize, our empirical findings supported earlier work on the causal nexus FDI-financial development. The unidirectional causal results from FDI to financial development were consistent with Abzari, Zarei, and Esfahani (2011) and Agbloyor et al. (2013) but the causality running from financial development to FDI were consistent with Desbordes and Wei (2017) and Yilmaz and Gavriletea (2018). Our bidirectional causality findings were also consistent with Gebrehiwot et al. (2016); Fauzel (2016) and Otchere et al. (2016).

\section{FINAL REMARKS}

This paper studied the causality between FDI inflows and financial development in a country-by-country timeseries framework for ECOWAS. The frequency domain test developed by Breitung and Candelon (2006) assesses the direction of causality at a given frequency. Frequency domain method allows decomposing in time-periods and shows the causality in different time frequencies.

Two different variables were chosen as indicators of financial development and the empirical findings indicated that the causality results may change depending on the measure of financial development employed. The findings suggested that the causality between financial development and FDI was mixed across different frequencies (i.e. in terms of permanent, medium or temporary causality).

Overall, country-by-country estimates revealed evidence of ( $i$ ) unidirectional causality, (ii) bidirectional causality and (iii) absence of causality between variables. These empirical findings lead to varied policy designs.

First, for the causality from FDI to finance, we suggest implementing more FDI-attracting policies to enhance financial development. Second, for the causality from financial development to FDI, we suggest implementing strategies that improve the level of the financial sector which will be beneficial for FDI flows to West Africa. Thirdly, for the two-way causality, the joint policies of financial reforms and investment-promoting policies for FDI can have a significant effect on the economic development of ECOWAS countries. In addition, policymakers should not only address the causal direction between FDI inflows and financial development but also whether it is temporal or permanent and therefore authorities must define measures to be taken accordingly.

Funding: This study received no specific financial support.

Competing Interests: The author declares that there are no conflicts of interests regarding the publication of this paper.

\section{REFERENCES}

Abzari, M., Zarei, F., \& Esfahani, S. S. (2011). Analyzing the link between financial development and foreign direct investment among D-8 group of countries. International Journal of Economics and Finance, 3(6), 148-156. Available at: https://doi.org/10.5539/ijef.v3n6p148.

Adjasi, C. K., Abor, J., Osei, K. A., \& Nyavor-Foli, E. E. (2012). FDI and economic activity in Africa: The role of local financial markets. Thunderbird International Business Revierw, 54(4), 429-439. Available at: https://doi.org/10.1002/tie.21474.

Agbloyor, E. K., Abor, J., Adjasi, C. K. D., \& Yawson, A. (2013). Exploring the causality links between financial markets and foreign direct investment in Africa. Research in International Business and Finance, 28, 118-134. Available at: https://doi.org/10.1016/j.ribaf.2012.11.001.

Agosin, M. R., \& Machado, R. (2005). Foreign investment in developing countries: Does it crowd in domestic investment? Oxford Development Studies, 33(2), 149-162. Available at: https://doi.org/10.1080/13600810500137749.

Al Nasser, O. M., \& Gomez, X. G. (2009). Do well-functioning financial systems affect the FDI flows to Latin America. International Research Journal of Finance and Economics, 29(July), 60-75. 
Alfaro, L., Chanda, A., Kalemli-Ozcan, S., \& Sayek, S. (2004). FDI and economic growth: The role of local financial markets. Journal of International Economics, 64(1), 89-1 12. Available at: https://doi.org/10.1016/s0022-1996(03)00081-3.

Alfaro, L., Chanda, A., Kalemli-Ozcan, S., \& Sayek, S. (2010). Does foreign direct investment promote growth? Exploring the role of financial markets on links. Journal of Development Economics, 91(2), 242-256. Available at: https://doi.org/10.1016/j.jdeveco.2009.09.004.

Bayar, Y., \& Ozel, H. A. (2014). Determinants of foreign direct investment inflows in the transition economies of European Union. Transition, $70(80,000.00), 90-000$.

Bekaert, G., Harvey, C. R., \& Lundblad, C. (2005). Does financial liberalization spur growth? Journal of Financial Economics, 77(1), 3-55. Available at: https://doi.org/10.1016/j.jfineco.2004.05.007.

Borensztein, E., De Gregorio, J., \& Lee, J.-W. (1998). How does foreign direct investment affect economic growth? Journal of International Economics, 45(1), 115-135. Available at: https://doi.org/10.1016/s0022-1996(97)00033-0.

Breitung, J., \& Candelon, B. (2006). Testing for short-and long-run causality: A frequency-domain approach. Journal of Econometrics, 132(2), 363-378. Available at: https://doi.org/10.1016/j.jeconom.2005.02.004.

Ciner, C. (2011). Eurocurrency interest rate links: A frequency domain analysis. International Review of Economics $\mathcal{E}^{2}$ Finance, 2O(4), 498-505. Available at: https://doi.org/10.1016/j.iref.2010.09.006.

Desbordes, R., \& Wei, S. J. (2017). The effects of financial development on foreign direct investment. Journal of Development Economics, 127(C), 153-168. Available at: https://doi.org/10.1016/j.jdeveco.2017.02.008.

Dolado, J. J., \& Lütkepohl, H. (1996). Making Wald tests work for cointegrated VAR systems. Econometric Reviews, 15(4), 369386. Available at: https://doi.org/10.1080/07474939608800362.

Durham, J. B. (2004). Absorptive capacity and the effects of foreign direct investment and equity foreign portfolio investment on economic growth. European Economic Review, 48(2), 285-306. Available at: https://doi.org/10.1016/s0014$2921(02) 00264-7$.

Enisan, A. A. (2017). Determinants of foreign direct investment in Nigeria: A Markov regime-switching approach. Review of Innovation and Competitiveness: A Journal of Economic and Social Research, 3(1), 21-48. Available at: https://doi.org/10.32728/ric.2017.31/2

Fauzel, S. (2016). Modeling the relationship between FDI and financial development in small Island economies: A PVAR approach. Theoretical Economics Letters, 6(3), 367-375. Available at: https://doi.org/10.4236/tel.2016.63041.

Gebrehiwot, A., Esfahani, N., \& Sayin, M. (2016). The relationship between FDI and financial sector development: The case of Sub-Saharan African region. International Journal of Regional Development, 3(1), 64-80.

Geweke, J. (1982). Measurement of linear dependence and feedback between multiple time series. Journal of the American Statistical Association, 77(378), 304-313. Available at: https://doi.org/10.2307/2287242.

Granger, C. (1969). Investigating causal relations by econometric models and cross-spectral methods. Econometrica, 37(3), 424438. Available at: https://doi.org/10.2307/1912791.

Hermes, N., \& Lensink, R. (2003). Foreign direct investment, financial development and economic growth. The Journal of Development Studies, $40(1), 142-163$.

King, R. G., \& Levine, R. (1993a). Finance and growth: Schumpeter might be right. Quarterly Journal of Economics, 108(3), 717738. Available at: https://doi.org/10.2307/2118406.

King, R. G., \& Levine, R. (1993b). Finance, entrepreneurship and growth. Journal of Monetary Economics, 32(3), 513-542.

Korgaonkar, C. (2012). Analysis of the impact of financial development on foreign direct investment: A data mining approach. Journal of Economics and Sustainable Development, 3(6), 70-78.

Lemmens, A., Croux, C., \& Dekimpe, M. G. (2008). Measuring and testing Granger causality over the spectrum: An application to European production expectation surveys. International Journal of Forecasting, 24(3), 414-431. Available at: https://doi.org/10.1016/j.ijforecast.2008.03.004.

Levine, R., Loayza, N., \& Beck, T. (2000). Financial intermediation and growth: Causality and causes. Journal of Monetary Economics, 46(1), 31-77. Available at: https://doi.org/10.1016/s0304-3932(00)00017-9. 
Levine, R., \& Zervos, S. (1998). Stock markets, banks, and economic growth. American Economic Revierw, 88(3), 537-558.

Njangang, H., Nembot, N. L., \& Nawo, L. (2019). The long-run and short-run effects of foreign direct investment on financial development in African Countries. African Development Review, 31(2), 216-229. Available at: https://doi.org/10.1111/1467-8268.12379.

Otchere, I., Soumaré, I., \& Yourougou, P. (2016). FDI and financial market development in Africa. The World Economy, 39(5), 651-678. Available at: https://doi.org/10.1111/twec.12277.

Sahina, S., \& Egeb, I. (2015). Financial development and FDI in Greece and neighbouring countries: A panel data analysis. Procedia Economics and Finance, 24, 583-588. Available at: https://doi.org/10.1016/s2212-5671(15)00640-1.

Seetanah, B. (2009). Is foreign direct investment growth conducive? New evidences from Sub-Saharan African countries, 19802005. Applied Econometrics and International Development, 9(2), 185-201.

Shen, C.-H., \& Lee, C.-C. (2006). Same financial development yet different economic growth-why? Journal of Money, Credit, and Banking, 38(7), 1907-1944. Available at: https://doi.org/10.1353/mcb.2006.0095.

Soumaré, I., \& Tchana, T. F. (2015). Causality between FDI and financial market development: Evidence from emerging markets. The World Bank Economic Review, 29(suppl_1), S205-S216. Available at: https://doi.org/10.1093/wber/lhv015.

Toda, H. Y., \& Yamamoto, T. (1995). Statistical inference in vector autoregressions with possibly integrated processes. Journal of Econometrics, 66(1-2), 225-250. Available at: https://doi.org/10.1016/0304-4076(94)01616-8.

Yilmaz, B., \& Gavriletea, M. D. (2018). Foreign direct investment inflows and financial development in central and eastern European Union countries: A panel cointegration andcausality. International Journal of Financial Studies, 6(2), 1-13. Available at: https://doi.org/10.3390/ijfs6020055.

Zakaria, Z. (2007). The causality relationship between financial development and foreign direct investment. Journal of Humanity, $5(2), 1-6$. 